\title{
PRAKTIK-PRAKTIK MANAJEMEN SDM STRATEGIK: PENGUJIAN EMPIRIS UNIVERSALISTIK DAN KONTINJENSI DALAM MENJELASKAN KINERJA ORGANISASIONAL ${ }^{1}$
}

\author{
Heru Kurnianto Tjahjono \\ Universitas Muhamadiyah Yogyakarta
}

\begin{abstract}
There are several perspectives to explain the relationship between strategic human resources management practices and organizational performance. This article discusses the controversy within each perspective, which is universalistic and contingency perspectives. This article tries to replicate some of Delerey and Doty's research on modes of theorizing in strategic human resource management. Strategic human resource management practices are identified into seven practices and are used to develop argumentation from that individual perspective. Organizational performance is measured by financial performance. The results show that argumentations from those two perspectives can explain the variation levels within financial performance.
\end{abstract}

Keywords: strategic HRM, universalistic, contingency, organizational performance

\section{PENDAHULUAN}

Dalam artikel yang ditulis oleh Delery dan Doty (1996) digambarkan pergeseran dramatik dalam area manajemen sumberdaya manusia (MSM). Pergeseran tersebut secara luas terkait dengan fokus MSM pada analisis mikro menuju analisis yang bersifat lebih makro dengan perspektif stratejik. Perspektif stratejik mendorong munculnya peran MSM stratejik. Peran tersebut semakin penting dalam organisasi baik manufaktur ataupun jasa, demikian pula organisasi privat dan publik. Peran MSM semakin berkembang, tumbuh dan meluas serta semakin kritikal dalam strategi dan bisnis (Gerhart dan Milkovich, 1990; Cutcher-Gershenfeld, 1991; Arthur, 1994; Ichniowski, Shaw dan Prennushi, 1994; McDuffie, 1995; Huselid, 1995; Huselid dan Becker, 1996 dalam Delery dan Doty, 1996).

Perspektif resource-based view (Barney, 1991) berpandangan bahwa kapabilitas sumberdaya manusia adalah sumberdaya potensial untuk sustainable competitive advantage bagi organisasi (Wright dan McMahan, 1992). Hal tersebut digambarkan sebagai kapabilitas sumberdaya manusia yang dapat membantu perusahaan memperoleh keunggulan kompetitif dengan praktik-praktik MSM dan mendorong fokus pada pelanggan.

Huselid (1995) berpendapat bahwa terdapat praktik-praktik terbaik manajemen sumberdaya manusia yang akan memberikan kontribusi kinerja keuangan sesuai tujuan stratejik mereka. Pandangan tersebut merefleksikan perspektif universalistik (Delaney, Lewin dan Ichniowsky, 1989; Huselid, 1993, 1995; Osterman, 1994; Pfeffer, 1994). Argumentasi yang dibangun adalah eksistensi "best practices" dalam pendekatan MSM stratejik (Delaney et al., 1989; Huselid, 1993 dan 1995; Osterman, 1994, Pfeffer, 1994; Terpstra dan Rozell, 1993 dalam Delery dan Doty, 1996).

Perspektif universalistik di atas dianggap terlalu sederhana dalam menjelaskan realitas. Pandangan berikutnya melihat bahwa interaksi bersifat lebih kompleks dibandingkan hubungan linear sederhana yang digambarkan oleh perspektif universalistik. Pandangan

\footnotetext{
${ }^{1}$ I am grateful to Ms. Fitri Nur Istiqomah, my assistance in this research
} 
berikutnya mengadopsi perspektif contingency (Fombrum et al., 1984; Dyer, 1985; Schuler dan Jackson, 1987; Milkovich, 1988, Lengnick dan Hall, 1988; Butler et al., 1991; Gomez-Mejia dan Balkin, 1992 dalam Delery dan Dotty, 1996). Perspektif tersebut menyatakan bahwa hubungan antara variabel independen dan variabel dependen yang relevan akan berbeda untuk tingkat variabel kontijensi kritikal yang berbeda. Perspektif ini mensyaratkan peneliti untuk memilih suatu variabel untuk selanjutnya menspesifikasi bagaimana praktik sumberdaya manusia secara individual akan berinteraksi dengan variabel contingency untuk menghasilkan kinerja organisasional.

Artikel ini berusaha mengartikulasikan, menguji dan menganalisis kedua perspektif tersebut, yaitu universalistik dan kontinjensi dalam penelitian empiris. Tujuh praktik-praktik MSM dipilih sebagai konsepsi kerja dalam masing-masing perspektif dan kinerja keuangan sebagai outcome dalam penelitian ini. Penelitian sebelumnya pernah dilakukan oleh Delery dan Doty (1996) yang mencakup tiga perspektif: universalistik, kontinjensi dan konfigurasional. Penelitian ini mereplikasi sebagian apa yang pernah diteliti oleh Delery dan Doty (1996) yaitu pada dua perspektif: universalistik dan kontinjensi. Kontribusi penting dalam penelitian ini adalah pada masalah setting penelitian BMT-BMT di Indonesia, khususnya di DIY dan Jawa Tengah.

\section{TINJAUAN LITERATUR DAN PENGEMBANGAN HIPOTESIS}

Penelitian tentang pengaruh praktik-praktik MSM terhadap kinerja organisasional menunjukkan bahwa praktik-praktik tersebut merupakan determinan penting dalam menjelaskan kinerja organisasional sehingga secara praktikal, seorang manajer dapat memilih praktik MSM tertentu yang dapat mendorong kinerja organisasional. Pembahasan kedua perspektif ini terkait dengan cara pandang kedua perspektif, yaitu universalistik maupun kontinjensi terhadap fenomena organisasional.

\subsection{Perspektif Universalistik}

Pernyataan teoritikal tentang perspektif universalistik adalah bahwa hubungan antara variabel independen tertentu dengan variabel dependen bersifat universal lintas populasi organisasi. Dalam pengembangan prediksi universalistik terhadap konsep MSM stratejik membutuhkan dua tahap (Delery dan Doty, 1996). Pertama, mengidentifikasi praktik-praktik MSM stratejik yang penting bagi organisasi tersebut. Kedua, argumentasi dan penjelasan bahwa terdapat hubungan antara praktik-praktik MSM secara individual terhadap kinerja organisasional harus disajikan.

Secara konseptual dan empirikal, hubungan antara praktik-praktik MSM dengan kinerja keseluruhan organisasi cukup banyak dijelaskan dalam literatur MSM. Namun demikian tidak semua praktik-praktik MSM akan berhubungan erat dengan kinerja. Hanya praktik-praktik MSM yang bersifat stratejik yang diyakini dapat menjelaskan kinerja keseluruhan organisasi dengan baik. Penentuan apakah praktik-praktik MSM dipertimbangkan stratejik atau tidak stratejik tergantung pada perkembangan konsensus di bidang tersebut. Delery dan Doty (1996) dengan mempertimbangkan konsep teoritikal yang diajukan oleh Osterman (1987), Sonnenfeld dan Peiperl (1988), Kerr dan Slocum (1987) dan Miles dan Snow (1984) dalam Delery dan Dotty (1996) mengajukan tujuh praktik-praktik MSM yang dipertimbangkan sebagai praktik-praktik MSM stratejik. Ketujuh praktik-praktik tersebut adalah: peluang karir internal (internal career opportunities), sistem pelatihan formal (formal training systems), penilaian kinerja (appraisals), pembagian keuntungan (profit sharing), keamanan kerja (employment security), mekanisme penyampaian pendapat (voice mechanism) dan definisi pekerjaan atau deskripsi pekerjaan (job description).

Secara lebih spesifik praktik-praktik tersebut adalah:

1. Peluang karir internal. Praktik MSM ini terkait dengan pasar buruh internal. Dengan kata lain, organisasi dapat memilih mempekerjakan dari dalam atau dari luar perusahaan. Peluang karir internal akan mendorong motivasi karyawan. 
2. Sistem pelatihan formal. Praktik MSM yang kedua merujuk pada sejumlah pelatihan tertentu bagi karyawan dalam organisasi atau perusahaan tersebut. Pelatihan yang tepat dapat meningkatkan kecerdasan dan keterampilan karyawan dalam bekerja.

3. Penilaian. Praktik MSM ini dapat berbasis pada hasil atau perilaku. Penilaian berbasis perilaku fokus pada perilaku individual sehingga dapat menjalankan pekerjaan dengan efektif. Sedangkan penilaian berbasis hasil hanya berfokus pada konsekuensi perilaku tersebut.

4. Perencanaan pembagian keuntungan. Praktik MSM keempat menekankan pada keterikatan individu pada kinerja organisasional sebagai satu bagian integral, yaitu sistem MSM stratejik. Karyawan diharapkan akan lebih memiliki kesamaan tujuan dengan perusahaan.

5. Derajat keamanan kerja. Praktik MSM ini memberikan keamanan kerja bagi karyawan. Praktik tersebut dinilai memiliki implikasi strategi yang penting, terutama terkait dengan upaya menciptakan rasa aman bagi karyawan

6. Mekanisme penyampaian pendapat, baik sistem pengaduan formal dan partisipasi dalam pengambilan keputusan telah muncul sebagai salah satu faktor kritikal. Dengan demikian karyawan merasa sebagai bagian yang dihargai dalam organisasi.

7. Derajat pekerjaan dengan spesifikasi tightly atau narrowly, artinya pekerjaan tersebut terkait erat dengan karyawan yang memahami isi pekerjaan secara tepat. Pekerjaan dibatasi dalam area atau bidang tertentu. Bila mereka yang menjalankan tugas tidak berkinerja baik maka tidak akan dipertimbangkan sebagai bagian dari pekerjaan itu. Tugas-tugas pekerjaan cenderung dibentuk oleh pendefinisian deskripsi pekerjaan yang baik dibandingkan aksi individu.

Schuler dan Jackson (1987) menyajikan daftar praktik-praktik MSM yang mempunyai pengaruh terhadap kinerja organisasional. Demikian pula beberapa penelitian lainnya pada bidang tersebut. Peneliti memandang bahwa ketujuh praktik tersebut bersifat kritikal pada sistem-sistem pengelolaan karyawan atau tenaga kerja dalam organisasi. Peneliti dapat menggunakan praktik-praktik tersebut secara individual dan kombinasi sebagai basis untuk hipotesis yang konsisten dengan alternatif perspektif teori yang diteliti. Dalam prediksi universalistik, peneliti mengadopsi perspektif universalistik yang menyatakan bahwa penggunaan yang lebih baik dari spesifik praktik-praktik tenaga kerja akan selalu menghasilkan prediksi yang lebih baik atau lebih buruk terhadap kinerja organisasional.

Leonard (1990) berpendapat bahwa organisasi yang memiliki perencanaan insentif jangka panjang terhadap para eksekutifnya akan mendorong meningkatkan return on equity (ROE) melampaui waktu empat tahun dibanding organisasi lainnya. Abowd (1990) dalam Leonard (1990) menemukan bahwa kompensasi manajerial berbasis pada kinerja keuangan organisasional signifikan berhubungan dengan kinerja keuangan di masa ke depan. Gerhart dan Milkovich (1990) dalam Leonard (1990) dan menemukan bahwa pembayaran yang bersifat mix akan berhubungan dengan kinerja keuangan. Terpstra dan Rozell (1993) menyatakan bahwa lima "best" praktik-praktik staffing dan menemukan penggunaan praktik-praktik yang memoderasi hubungan positif dengan kinerja organisasional. Akhirnya Huselid (1995) mengidentifikasi kinerja organisasional dan level outcomes dan kelompok high performance praktik-praktik kerja. Huselid (1995)memfokuskan pada penggunaan praktik MSM secara simultan dan menyimpulkan bahwa MSM organisasi yang sesuai secara signifikan berhubungan debngan turnover, produktifitas organisasional dan kinerja keuangan. Secara keseluruhan level dukungan menghasilkan prediksi-prediksi universalistik yang menunjukkan bahwa perspektif universalistik adalah perspektif teoritikal valid untuk para ahli di bidang tersebut. Berdasarkan konstruksi teori dan konsep di atas, maka penulis menduga terdapat hubungan positif antara praktik-praktik MSM yang high performance akan memprediksi hubungan positif antara ketujuh praktik-praktik MSM dengan kinerja keuangan organisasi yang diproksi dengan ROA. Hipotesis 1 sebagai berikut: terdapat hubungan positif antara kinerja keuangan organisasi dan praktik-praktik MSM yang meliputi: 1) penggunaan karir internal; 2) 
sistem-sistem pelatihan formal; 3) penilaian berorientasi hasil; 4) kompensasi berbasis kinerja; 5) keamanan kerja karyawan; 6) mekanisme penyampaian pendapat (voice mechanism) dan pendeskripsian pekerjaan secara lebih luas (broadly defined jobs).

2.2. Perspektif Kontinjensi

Argumentasi yang dikonstruksi dalam perspektif ini adalah bahwa hubungan atau interaksi antar variabel tidak bersifat hubungan linier sederhana seperti yang dikelompokkan ke dalam teori-teori universalisitik (Schoonhoven, 1981; Van De Ven dan Drazin, 1985; Venkatraman, 1989 dalam Delery dan Dotty, 1996). Perspektif ini menempatkan hubungan antara variabel independen dan variabel dependen yang relevan akan berbeda pada derajat yang berbeda pada variabel kontinjensi kritikal. Selanjutnya perspektif kontinjensi ini membutuhkan seorang peneliti yang akan memilih teori dan kemudian menspesifikasikan bagaimana praktik-praktik MSM secara individual akan berinteraksi dengan strategi perusahaan sehingga menghasilkan kinerja organisasi.

Dalam pemilihan tipologi yang akan digunakan sebagai variabel kontinjensi, penulis merujuk pula pada penelitian yang dilakukan oleh Delery dan Doty (1996). Menurut Delery dan Doty, pemilihan tipologi Miles dan Snow dalam teori strategi, struktur dan proses untuk studi ini memiliki beberapa keunggulan. Pertama, tipologi tersebut menunjukkan prediktor yang relatif powerful terhadap keefektifan organisasional (Doty et al., 1993 dalam Delery dan Doty, 1996). Kedua, Miles dan Snow (1984) dalam Delery dan Doty (1996) secara eksplisit menyatakan bahwa teori mereka mempunyai implikasi terhadap kebijakan MSM organisasi. Ketiga, teori tersebut secara umum telah digunakan dalam literatur MSM. Terakhir, studi-studi saat ini menyajikan interpretasi teori Miles dan Snow dapat diinterpretasikan sebagai teori kontinjensi ( Hambrick, 1983: Zajac dan Shortell, 1989).

Meskipun demikian teori Miles and Snow juga dapat digunakan dalam perspektif konfigurasional (Doty et al., 1993, Segev, 1989) seperti yang dilakukan oleh Delery dan Doty (1996) dalam penelitiannya. Namun dalam artikel ini, perspektif konfigurasional tidak digunakan. Penginterpretasian teori Miles dan Snow (1978) sebagai teori kontinjensi membutuhkan peneliti untuk mengidentifikasi variabel tunggal yang membedakan strategi alternatif yang menspesifikasi teori aslinya. Beberapa penelitian terdahulu telah menggunakan produk, servis dan inovasi sebagai variabel kontinjensi (Hambrick, 1983; Zajac dan Shortell, 1989). Perusahaan-perusahaan yang memiliki inovasi yang tinggi dipertimbangkan sebagai prospectors, sedangkan perusahaan yang melakukan inovasi yang moderat dipertimbangkan sebagai analyzers dan perusahaan yang sedikit melakukan inovasi dipertimbangkan sebagai defenders.

Dalam penelitian ini, seluruh perusahaan dikarakterisasikan dengan variabel kontinjensi inovasi. Dalam prediksi kontinjensi, hubungan antara penggunaan praktik-praktik MSM spesifik dan kinerja organisasional akan kontinjen pada strategi organisasional (Jackson et al., 1989) yang berdampak pada kesuksesan implementasi strategi. Eisenhardt (1988), Fama (1980), serta Fama dan Jensen (1983) dalam Delery dan Doty (1996) juga menyatakan hal yang sama, yaitu jika karyawan mengetahui apa yang harus mereka lakukan maka kebijakan dan prosedur perusahaan akan mendukung mereka untuk konsisten dengan perilaku tersebut.

Secara ringkas peneliti berpendapat bahwa implementasi praktik-praktik MSM akan mendorong perilaku karyawan sehingga konsisten dengan strategi organisasional. Kesejajaran antara strategi dan praktik-praktik MSM mendorong organisasi mencapai kinerjanya dengan lebih baik. Hipotesis 2 adalah sebagai berikut: Strategi organisasional memoderasi hubungan positif antara praktik-praktik MSM dan kinerja organisasional.

Berdasarkan paparan dan hipotesis tersebut, maka model penelitian yang digunakan adalah sebagai berikut: 


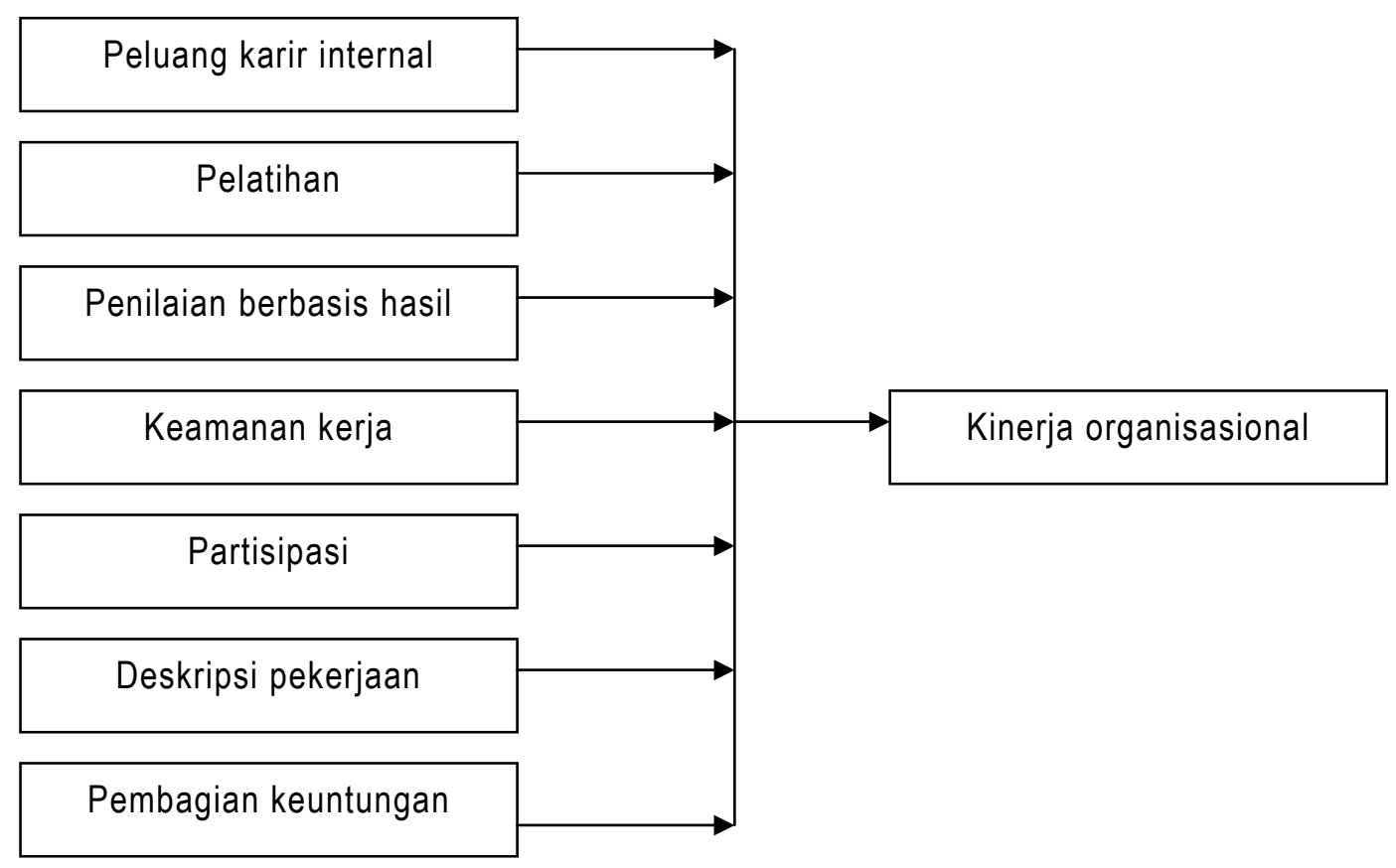

Gambar 1

Perspektif Universalistik

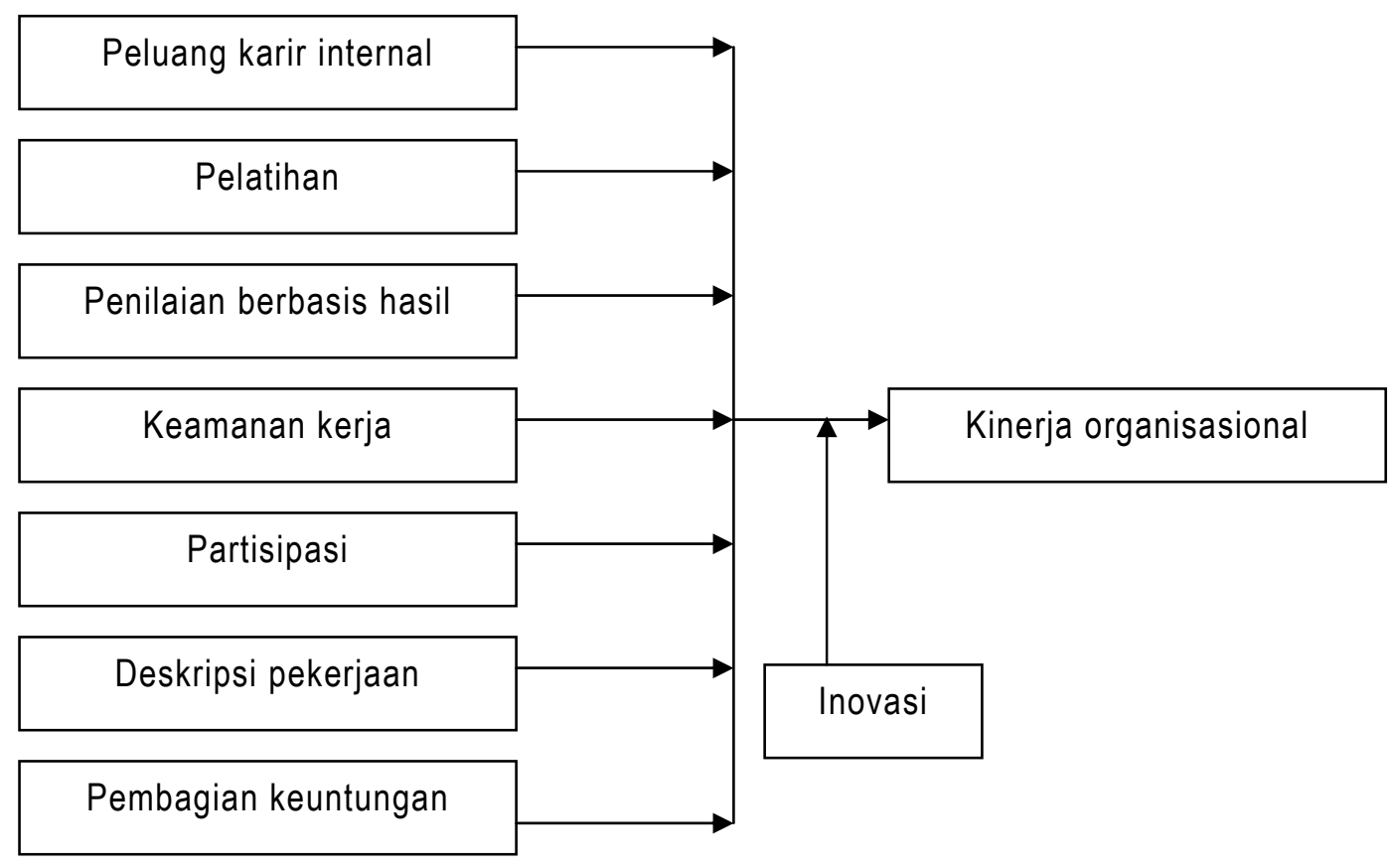

Gambar 2

Perspektif Kontinjensi

\section{PEMILIHAN SAMPEL DAN METODA PENGUMPULAN DATA}

Penelitian ini ditujukan untuk memahami dua perspektif yang telah dibahas sebelumnya dalam memahami fenomena praktik-praktik MSM dan kinerja organisasional. 
Penelitian ini dilakukan pada industri tunggal yang spesifik sehingga diharapkan akan lebih mudah dalam mengendalikan perbedaan-perbedaan dalam industri tersebut. Industri yang dipilih adalah industri lembaga keuangan mikro syari'ah atau populer disebut BMT. Pilihan pada industri tersebut didasarkan pada beberapa alasan, yaitu: 1) sejak tahun 1994, industri ini mulai berkembang di Indonesia, khususnya propinsi DIY dan Jawa Tengah dan selanjutnya tumbuh pesat dan digerakkan oleh komunitas orang yang relatif berpendidikan cukup baik: 2) Seperangkat praktik-praktik MSM sudah mulai dikembangkan dengan baik oleh organisasi BMT baik secara individu maupun kelompok asosiasi di antara BMT-BMT tersebut; 3) pemilihan industri ini sekaligus menjelaskan batasan generalisasi dalam menginterpretasikan hasil-hasil penelitian.

Peneliti menggunakan populasi BMT-BMT di propinsi DIY dan Jawa Tengah. Teknik sampling yang digunakan adalah convenience sampling. Data responden dikumpulkan dari satu sumber (single source) yaitu manajer BMT dengan teknik purposive. Pertimbangannya adalah bahwa organisasi BMT tidak terlalu besar dan manajer BMT cukup memiliki informasi yang strategis.

Data dikumpulkan dengan kuesioner secara personal (personally administered questionnaires) yaitu dengan cara mendatangi BMT yang digunakan sebagai sampel dan meminta pimpinan BMT yang bersangkutan untuk mengisi kuesioner yang telah disediakan. Peneliti dibantu oleh seorang asisten peneliti untuk mengumpulkan kuesioner pada beberapa BMT di DIY dan Jawa Tengah. Jumlah data BMT yang dapat digunakan dalam penelitian ini sebanyak 30 BMT.

Semua variabel independen $(X)$ dan variabel kontinjensi diukur berdasarkan adaptasi kuesioner penelitian yang dilakukan oleh Delery dan Doty (1996). Sedangkan kinerja keuangan diukur berdasarkan perkiraan pimpinan atas ROA yang dicapai perusahaan (dalam persentase). Selanjutnya dari ROA yang dicapai diberikan skor berdasarkan selisih ROA tiap tahunnya dan juga berdasarkan pengamatan dan diskusi selama melakukan kunjungan ke BMT yang bersangkutan. Skor yang diberikan di mulai dari angka 1 untuk kinerja keuangan sangat buruk sampai 5 untuk kinerja keuangan sangat baik.

Penilaian atau pemberian skor dari kuesioner untuk variabel independen dan variabel kontinjensi dengan menggunakan Skala Likert. Kinerja keuangan $(Y)$ diukur berdasarkan perkiraan ROA dalam tiga tahun terakhir yaitu tahun 2001, 2002, 2003. ROA (Return On Asset) adalah tingkat pengembalian/keuntungan atas total aktiva yang dimiliki BMT. Peluang karir internal (X1) adalah kesempatan jenjang karir yang disediakan oleh BMT berdasarkan kemampuan yang dimiliki masing-masing karyawan.

Pelatihan (X2) adalah pemberian tambahan ilmu pengetahuan baik itu dari luar BMT maupun dari dalam BMT. Penilaian berdasar hasil (X3) adalah penilaian yang dilakukan oleh atasan untuk melakukan penilaian yang didasarkan pada hasil pekerjaan yang dilakukan karyawan. Keamanan kerja (X4) adalah jaminan atas keamanan dan kenyamanan karyawan saat mereka bekerja sehingga karyawan memiliki intention to live (keinginan untuk te tap tinggal/kerja di BMT). Partisipasi (X5) adalah BMT memberikan peran aktif bagi karyawannya untuk menyampaikan pendapatnya dalam pengambilan keputusan organisasional. Deskripsi pekerjaan (X6) adalah gambaran tentang pekerjaan yang akan dilakukan oleh karyawan. Profit sharing atau pembagian keuntungan (X7) adalah ukuran besarnya bonus yang diberikan oleh BMT kepada karyawannya adalah sebanding dengan keuntungan yang diterima BMT. Inovasi adalah sifat kreatif dari manajer BMT untuk memenangkan persaingan dalam mendapatkan nasabah. Inovasi dapat dilakukan pada pelayanan, produk BMT ataupun manajemen yang dipakai.

\section{ANALISIS HASIL DAN PEMBAHASAN}

Total kuesioner yang dapat digunakan sebanyak 30 kuesioner dari 44 kuesioner yang didistribusikan. Lama berdiri masing-masing BMT kurang lebih 4-5 tahun. Sebelum data dianalisis, terlebih dahulu dilakukan pengujian kualitas data dengan menggunakan uji 
reliabilitas dan validitas. Uji reliabilitas digunakan untuk menguji konsistensi. Uji reliabilitas yang akan digunakan adalah reliabilitas konsistensi internal (internal consistency reliability), yaitu mengukur konsistensi di antara butir-butir pernyataan dari kuesioner. Indikatorrnya adalah Cronbach's Alpha dengan rule of thumb sebesar 0.6 (Nunnaly, 1969 dalam Ghozali, 2002). Sedangkan uji validitas dilakukan untuk menguji keakuratan instrumen pengukur (kuesioner) dengan menggunakan korelasi Pearson product moment.

Untuk menguji hipotesis, data yang terkumpul akan dianalisis dengan software komputer yaitu program SPSS (Statistical Package for the Sosial Sciences) 11.5 dengan menggunakan alat bantu statistik regresi berganda dan regresi hirakikal. Regresi berganda digunakan untuk menguji hipotesis pertama atau menggunakan persepsi universalistik. Sedangkan regresi hirarkikal digunakan untuk menguji hipotesis kedua.

Uji validitas dapat dilakukan dengan menggunakan uji korelasi antara skor masingmasing pertanyaan dengan total skor (Ghozali, 2002). Dari uji Korelasi Pearson terlihat bahwa korelasi antara masing-masing skor pertanyaan terhadap total skor butir-butir pertanyaan menunjukkan hasil yang signifikan pada taraf sigifikansi $5 \%$ dan $1 \%$. sehingga dinyatakan valid.

Uji Reliabilitas untuk mengukur suatu keusioner yang merupakan indikator dari variabel atau konstruk. Suatu kuesioner dikatakan reliabel atau handal jika jawaban sesorang terhadap pertanyaan adalah konsisten atau stabil dari waktu ke waktu (Ghozali, 2002). Pengukuran reliabilitas dapat dilakukan dengan One shot atau pengukuran sekali saja. Di sini pengukuran hanya sekali dan kemudian hasilnya dibandingkan dengan pertanyaan lain atau mengukur korelasi antar jawaban pertanyaan. Untuk melakukan uji reliabilitas ini peneliti menggunakan SPSS dengan uji stastistik Cronbach Alpha. Suatu konstruk atau variabel dikatakan reliable jika memberikan nilai Cronbach Alpha > 0,60 ( Nunnally, 1969 dalam Ghozali, 2002).

Ringkasan hasil uji reliabilitas dan validitas dapat dilihat dalam tabel 1 dan 2.

Tabel 1

Ringkasan Uji Reliabilitas

\begin{tabular}{lcl}
\hline \multicolumn{1}{c}{ variabel } & Alpha & Status \\
\hline Peluang karir internal & 0,6188 & Reliable \\
Pelatihan & 0,7542 & Reliable \\
Penilaian berdasar hasil & 0,8697 & Reliable \\
Keamanan kerja & 0,6112 & Reliable \\
Partisipasi & 0,7004 & Reliable \\
Deskripsi perkerjaan & 0,6470 & Reliable \\
Inovasi & 0,732 & Reliable \\
\hline
\end{tabular}


Tabel 2

Uji Korelasi Pearson Antar Variabel

\begin{tabular}{|c|c|c|c|c|c|c|c|c|}
\hline Variabel & perform & Career & Train & Appr & jobsec & Partisip & jobdesk & profsh \\
\hline Career & $0,538^{* *}$ & )$^{(0,6188}$ & & & & & & \\
\hline Training & 0,080 & 0,240 & $(0,7542)$ & & & & & \\
\hline Appraisal & 0,286 & $0,41^{* * *}$ & 0,293 & )$^{(0,8697}$ & & & & \\
\hline $\begin{array}{l}\text { Jobsecurt } \\
\text { y }\end{array}$ & 0,192 & $-0,006$ & $-0,232$ & 0,337 & $(0,6112)$ & & & \\
\hline $\begin{array}{l}\text { Partisipas } \\
\text { i }\end{array}$ & 0,043 & $0,37^{* * *}$ & $0,595^{* *}$ & $0,658^{* *}$ & 0,066 & $(0,7004)$ & & \\
\hline $\begin{array}{l}\text { Jobdeskri } \\
\mathrm{p}\end{array}$ & 0,300 & $0,41^{* * *}$ & $0,579^{* *}$ & $0,555^{* *}$ & 0.154 & $0,568^{* *}$ & $(0,6470)$ & \\
\hline Profshar & $-0,129$ & $-0,111$ & 0,176 & $-0,029$ & 0,158 & 0,107 & 0,162 & $(0,732)$ \\
\hline Inovasi & 0,051 & $0,41^{* * *}$ & 0,325 & 0,173 & $-0,245$ & 0,040 & 0,168 & $-0,229$ \\
\hline
\end{tabular}

Pada uji korelasi di atas dapat dilihat bahwa antar variabel independen dan antara variabel independen dengan variabel dependen memang terdapat hubungan walaupun ada beberapa yang tidak cukup signifikan. Demikian pula hubungan yang cukup erat antara beberapa variabel independen. Menurut Ghozali (2002), jika angka korelasi antar variabel independen mencapai $80 \%$ maka terdapat multikolinearitas atau pengukuran variabel yang sama tetapi dianggap berbeda dari korelasi tersebut. Jika hal ini terjadi maka data tersebut tidak dapat digunakan untuk melakukan analisis regresi.

Tabel 3

Hasil Uji t Untuk Pengujian Universalistik

\begin{tabular}{|c|c|c|c|c|c|c|}
\hline \multirow[b]{2}{*}{ Model } & & \multicolumn{2}{|c|}{$\begin{array}{c}\text { Unstandardize } \\
\text { Coefficients }\end{array}$} & \multirow{2}{*}{$\begin{array}{c}\text { Standardized } \\
\text { Coefficients } \\
\text { Beta }\end{array}$} & \multirow[b]{2}{*}{$t$} & \multirow[b]{2}{*}{ Sig } \\
\hline & & $B$ & $\begin{array}{l}\text { Std. } \\
\text { Error }\end{array}$ & & & \\
\hline \multirow[t]{8}{*}{1} & (Constant) & 1.567 & 1.72 & & 0.911 & 0.372 \\
\hline & CAREER & 0.579 & 0.207 & 0.529 & 2.796 & 0.011 \\
\hline & TRAINING & 0.241 & 0.421 & 0.141 & 0.573 & 0.573 \\
\hline & APPRAI & 0.134 & 0.209 & 0.165 & 0.641 & 0.528 \\
\hline & JOBSECUR & 0.234 & 0.237 & 0.195 & 0.984 & 0.336 \\
\hline & PARTICIP & -0.643 & 0.397 & -0.426 & -1.62 & 0.119 \\
\hline & JOBDESK & 0.169 & 0.297 & 0.138 & 0.568 & 0.576 \\
\hline & PROFITSH & -0.099 & 0.176 & -0.099 & -0.562 & 0.58 \\
\hline
\end{tabular}

a. Dependent Variable: PERFORMA

Uji t pada table 3 di atas menyatakan bahwa dari ketujuh praktik MSM hanya peluang karir internal yang mempunyai pengaruh signifikan terhadap kinerja keuangan. Namun demikian hasil telah menunjukkan dukungan pada perspektif universalistik. 
Tabel 4

Hasil pengujian regresi kontinjensi

\begin{tabular}{|c|c|c|}
\hline \multirow{2}{*}{ Variabel-variabel } & \multicolumn{2}{|c|}{ ROA } \\
\hline & $\beta$ & $\Delta R^{2}$ \\
\hline \multicolumn{3}{|l|}{ PRAKTIK - PRAKTIK MSM } \\
\hline Peluang karir internal & $0.590 * * *$ & 0.29 \\
\hline Pelatihan & 0.137 & 0.006 \\
\hline Penilaian kinerja & 0.233 & 0.082 \\
\hline Pembagian keuntungan & 0.129 & 0.017 \\
\hline Keamanan kerja & 0.230 & 0.031 \\
\hline Mekanisme partisipasi & 0.064 & 0.002 \\
\hline Deskripsi pekerjaan & 0.368 & 0.090 \\
\hline INOVASI & 0.087 & 0.003 \\
\hline \multicolumn{3}{|l|}{ INTERAKSI-INTERAKSI } \\
\hline INOVASI x 1 & 0.563 * & 0.122 \\
\hline INOVASI $\times 2$ & 0.411 & 0.045 \\
\hline INOVASI $\times 3$ & 0.045 & 0.001 \\
\hline INOVASI x 4 & 0.177 & 0.011 \\
\hline INOVASI $\times 5$ & 0.626 & 0.088 \\
\hline INOVASI x 6 & 0.354 & 0.034 \\
\hline INOVASI $\times 7$ & $0.634^{* *}$ & 0.157 \\
\hline
\end{tabular}

** * korelasi signifikan pada 0.01

** korelasi signifikan pada 0.05

* $\quad$ korelasi signifikan pada 0.1

Tabel 4 menunjukkan bahwa interaksi inovasi dan peluang karir internal berpengaruh signifikan terhadap kinerja keuangan dengan $a=0.1$. Interaksi inovasi dan deskripsi pekerjaan berpengaruh signifikan terhadap kinerja keuangan dengan $a=0.05$ Keduanya mendukung argumentasi pada hipotesis kontinjensi.

\section{SIMPULAN}

Tampak bahwa dari tujuh variabel praktik-praktik MSM, hanya peluang karir internal yang mempengaruhi kinerja keuangan secara kuat. Namun demikian hasil empiris tersebut mendukung argumentasi perspektif universalistik. Hal tersebut menunjukkan bukti bahwa terdapat "best practices" di dalam praktik-praktik MSM stratejik.

Pembahasan selanjutnya untuk pengujian hipotesis kedua atau pengujian secara kontinjensi. Perspektif ini membahas bagaimana inovasi mempengaruhi hubungan antara praktik-praktik MSM stratejik dengan kinerja keuangan. Dari hasil analisis dapat dikatakan bahwa inovasi merupakan variabel pemoderasi dari hubungan beberapa praktik MSM terhadap kinerja keuangan.

Mengenai variabel pemoderasi, Prescott (1986) menyatakan bahwa terdapat beberapa tipe variabel pemoderasian yang sering dibahas dalam penelitian, di antaranya yaitu quasi moderators dan pure moderators. Dikatakan quasi moderators jika variabel moderasi berhubungan secara signifikan dengan variabel independen (ditunjukkan dengan uji korelasi antar variabel) dan berpengaruh signifikan pada analisis regresi. Sedangkan dikatakan sebagai pure moderators jika variabel moderasi tidak berhubungan secara signifikan dengan variabel independen (juga dibuktikan dengan uji korelasi antar variabel) dan berpengaruh 
signifikan yang dibuktikan dengan analisi regresi. Hasil menunjukkan bahwa inovasi berperan sebagai pure moderators.

Beberapa kelemahan dalam penelitian ini adalah: 1) desain penelitian cross-section menyebabkan penelitian ini tidak dapat menangkap secara utuh hubungan sebab akibat yang terjadi di dalamnya; 2) hasil penelitian ini mempunyai kemampuan generalisasi yang rendah, karena kecilnya sampel dan teknik sampling yang digunakan bersifat non-random; 3) untuk merepresentasikan unit analisis organisasi, peneliti menggunakan satu sumber, yaitu manajer BMT; 4) tipe pekerjaan tidak diidentifikasi secara detil dalam penelitian ini.

Pengembangan kajian mengenai perspektif ini perlu dilakukan dengan desain penelitian longitudinal sehingga dapat lebih menangkap fenomena hubungan sebab akibat secara lebih baik. Di samping itu, teknik random sampling, teknik pengumpulan data dengan multi sources penting dipertimbangkan agar hasil lebih menggambarkan fenomena yang dikaji. Identifikasi jenis pekerjaan juga menjadi hal yang penting, terkait dengan variasi yang tinggi antara tipe perkerjaan.

\section{DAFTAR PUSTAKA}

Arthur, (1994), "Effects of Human Resources System on Manufacturing Performance and Turnover", Academy of Management Journal, 37: 670-687.

Bacharach, (1989), "Organizational Theories: Some Criteria for Evaluation", Academy of Management Review, 14: 496-515.

Bae dan Lawler, (2000), "Organizational and HRM Strategies in Korea: Impact on Firm Performance in An Emerging Economy", Academy of Management Journal, 43: 502-517.

Baird dan Meshoulam, (1988), "Managing Ttwo Fits of Strategic Human Resource Management", Academy of Management Review, 13: 116-128.

Barney, (1991), "Firm Resources and Sustained Competitive Advantage", Journal of Management, 17: 99120.

Becker, (1996), "The Impact of Human Resources Management on Organizational Performance: Progress and Prospects", Academy of Management Journal, 39: 779-801.

Butler, Ferris dan Napier, (1991), Strategy and Human Resources Management, Cincinnati: SouthWestern.

Conner dan Ulrich, (1996), "Human Resources Roles: Creating Value, Not Rethoric", Human Resources Planning, 19 (3): 38-49.

Delaney dan Huselid, (1996), "The Impact of Human Resources Management Practices on Perceptions of Organizational Performance", Academy of Management Journal, 39: 949-969.

Delery dan Doty, (1996), "Modes of Theorizing in Strategic Human Resource Management: Tests of Universalistic, Contingency and Configurational Performance Predictions", Academy of Management Journal, 39: 802-835.

Earley dan Erez, (1997), New Perspectives on International Industrial Organizational Psychology, The New Lexington Press San Fransisco. 
Ghozali, Imam, (2001), Aplikasi Analisis Multivariate Dengan Program SPSS, Badan Penerbit Universitas Diponegoro, Semarang.

Hambrick, (1983), "Some Tests of The Effectiveness and Functional Attributes of Miles and Snow's Strategic Types", Academy of Management Journal, 26: 2-26.

Hitt, Bierman, Shimizu, dan Kochhar, (2001), "Direct and Moderating Effects of Human Capital on Strategy and Performance in Professional Service Firms: A Resource-Based Perspective", Academy of Management Journal, Vol.44. No.1: 13-28.

Huselid, (1995), "The Impact of Human Resources Management Practices on Turnover, Productivity and Corporate Financial Performance", Academy of Management Journal, 38: 635-672.

Huselid, Jackson, dan Schuler, (1997), "Technical and Strategic Human Resources Management Effectiveness as Determinants of Firm Performance", Academy of Management Journal, 40: 171188.

Jackson, Schuler, dan Rivero, (1989), "Organizational Characteristics as Predictors of Personnel Practices", Personnel Psychology, 42: 727-786.

Kamoche, (1996), "Strategic Human Resource Management Within a Resource-Capability View of The Firm, Journal of Management Studies, 33: 213-233.

Lado dan Wilson, (1994), "Human Resource Systems and Sustained Competitive Advantage: A Competency-Based Perspective", Academy of Management Review, 19: 699-727.

Leonard, (1990), "Excecutive Pay and Firm", Industrial and Labor Relation Review, 43: 13-29.

Lepak dan Snell, (1999), "The Human Resource Architecture: Toward a Theory of Human Capital Allocation and Development", Academy of Management Review, 24: 31-48.

Miles dan Snow, (1978), Organizational Strategy, Structure and Process, New York: McGraw-Hill.

Miner, B. Johns, (1980), Theories of Organizational Behavior, USA: The Dryden Press.

Mintzberg, Ahlstrand, dan Lampel, (1998), Strategy Safari: A Guided Tour Through The Wilds of Strategic Management, The Free Press.

Pfeffer, J., (1982), Organizations and Organization Theory, USA: Pitman Publ. Inc.

Prescott, E. John, (1986), "Environments As Moderators of Relationship Between Strategy and Performance", Academy of Management Journal, Vol.29, No.2: 329-346.

Sandberg, (2000), "Understanding Human Competence At Work: An Interpretative Approach", Academy of Management Journal, Vol.43. No.1: 9-25.

Schuler dan Jackson, (1987), "Linking Competitive Strategies With Human Resource Management Practices", Academy of Management Excecutive, 1(3): 207-219.

Snell dan Youndt, (1995), "Human Resource Management and Firm Performance: Testing a Contingency Model of Executive Controls", Journal of Management, 21: 711-737. 
KINERJA, Volume 9, No.2, Th. 2005: Hal. 123-134

Smircich, (1983), "Concepts of Culture and Organizational Analysis", Administrative Science Quarterly, 28: 339-358.

Teare dan Dealtry, (1998), "Building \& Sustaining a Learning Organization", The Learning Organization, MCB University Press. Vol.5. No.1: 47-60.

Terpstra dan Rozell, (1993), "The Relationship of Staffing Practices to Organizational Level Measures of Performance", Personnel Psychology, 46: 27-48.

Wayne, Liden, Kraimer, dan Graf, (1999), "The Role of Human Capital, Motivation \& Supervisor Sponsorship in Predicting Career Success, Journal of Organizational Behavior, No.20: 577-595.

Welbourne dan Cyr, (1999), "The Human Resource Executive Effect in Initial Public Offering Firms", Academy of Management Journal, Vol.42. No.6: 616-629.

Wright dan McMahan, (1992), "Theoritical Perspectives for Strategic Human Resources Management, Journal of Management, 18: 295-320.

Wright dan Snell, (1998), "Toward a Unifying Framework for Exploring Fit and Flexibility in Strategic Human Resource Management", Academy of Management Review, 23: 756-772. 